\title{
Cartografia do desassossego: \\ UM OLHAR CLÍNICO-POLÍTICO PARA O ENCONTRO ENTRE OS PSICÓLOGOS E O CAMPO JURÍDICO ${ }^{\star}$
}

Ana Claudia Camuri ${ }^{\star}$

Palavras chaves: Psicologia Jurídica; produção de subjetividades; exame criminológico; depoimento sem dano.

Esta pesquisa analisa as forças que estão em jogo no encontro entre a psicologia e o campo jurídico. Partimos de uma perspectiva clínico-política, que se utiliza de alguns escritos de Foucault, Deleuze, Guattari, Wacqüant, Espinosa, Lourau, Fernando Pessoa, dentre outros. Iniciamos o trabalho com uma análise de implicações a cerca do processo de se fazer pesquisa e se fazer pesquisador. Posteriormente, pensaremos com Foucault, as condições e circunstâncias que possibilitaram o encontro entre a psiquiatria, a criminologia, a psicanálise e a psicologia, nas sociedades disciplinares, assim como a forma como estes saberes colonizaram o judiciário. Em seguida procuramos discutir como esse encontro acontece no contemporâneo, caracterizado pelos dispositivos de controle social no qual observamos que, a colonização se tornou mútua, pois também os saberes e as práticas jurídicas colonizam a psicologia e a psicanálise. Os principais instrumentos metodológicos utilizados foram: entrevistas, observação participante e análise dos discursos e práticas dos psicólogos e dos operadores do direito. Além disso, escolhemos como analisadores alguns procedimentos jurídicos que contam com a participação do psicólogo, pois denunciam o funcionamento desses saberes e desse campo. Buscamos também conhecer os efeitos negativos desse encontro na vida desses profissionais e o desassossego que se torna visível por meio de suas lutas pela construção de outras práticas nesse campo, que estejam a favor da vida e da liberdade e não do encarceramento. Para finalizar recorremos a algumas idéias abolicionistas, para pensarmos na possibilidade de outras práticas também na área do direito, pois acreditamos que não é possível pensar em outra psicologia nesse campo, se não pensarmos em outro direito.

^ Dissertação apresentada ao Programa de Pós-Graduação em Psicologia do Departamento de Psicologia da Universidade Federal Fluminense, como requisito parcial para a obtenção do título de Mestre em Psicologia. Orientadora: Prof. Dra. Cristina Mair B. Rauter. Área de concentração: Clínica e Subjetividade. Data da defesa: 09/09/2010.

$\star \star$ Psicóloga. Mestre em Psicologia pela Universidade Federal Fluminense. .

E-mail: anaclaudiacamuri@yahoo.com.br 